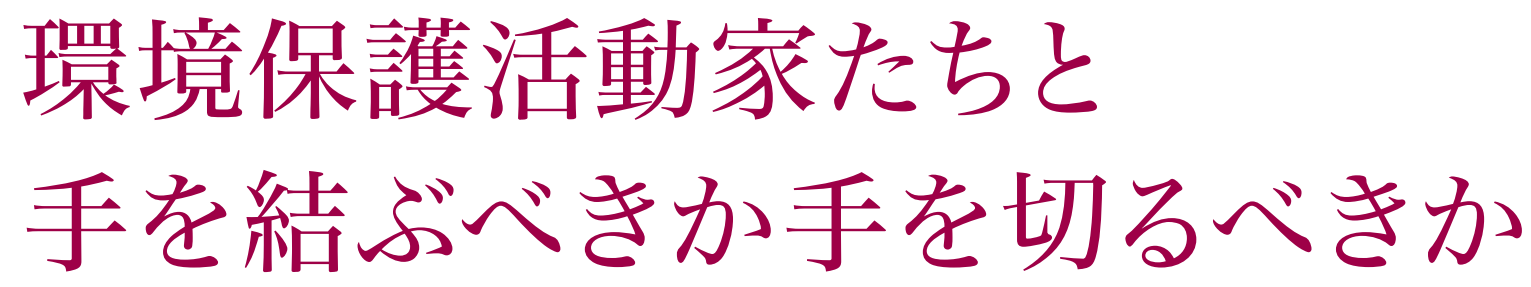

\title{
To build bridges, or to burn them
}

\author{
Nature Vol.443(481)/5 October 2006
}

科学技術に苛立ちを強めている環境保護活動家たちを、理屈が通じない相手として退けるべきではない。

「誰の意見も等しく貴重だとは限らない。」

もしこの言葉が驚きをよぶとすれば、それは、教室の 中やラジオのトーク番組、ブログや政治活動などで、 誰かがいった独断的な意見にもすべて価值があるとみ なされる文化が存在していることの証である。こうし た文化が、科学研究施設への放火など各種の戦法を用 いる少人数の環境保護団体を生み出したといっては誇 張になるだろう。しかし、両者はつながっている、と いう主張は確かにできる。

Nature 10 月 5 日号には、米国北西部での過激な環 境保護運動に関する記事が揭載されている。それによ ると環境保護活動家たちは、彼らが望ましくないとみ なした研究を行っている研究施設を襲撃したとされる。 この襲撃に実際に関与した人々の数は案外少なかった が、彼らの支援母体はかなり大きい。

環境保護研究に携わる科学者は、この大きい支援母 体との対話を維持すべきである。ただし、それは容易 なことではない。感情的な議論に対して上から物をい う態度、もしくは懐疑的な態度を少しでもみせてしま えば、論理性があいまいでも非常に固い信念に支えら れている一部の世論は、直ちに遠ざかっていくだろう。
問題の襲撃事件の実行者たちは「地球解放戦線」(ELF) のメンバーだと名乗っている。彼らが放火したのは、例 えば樹木の遺伝子操作や野生動物の間引きにかかわって いると彼らが確信した研究施設だった。彼らの動機はま ず間違いなく、問題とする科学研究の倫理性に関する自 分たちの判断が他のすべての人々の判断に勝る、という 信念からきている。抢そらくそれに加えて、犯罪行為そ のものがもたらすスリルもあっただろう。

感情的な反応

ELF の公式声明や著作物、その犯罪行為の支援者との インタビューなどをみると、多くのこうした活動家たち が、直感や感情的な反応、個人主義にあまりにも大き な価值を置き、その中で堂々巡りをしていることが明ら かである。この種の活動家は、ロマン主義の情熱的な アメリカ人だとみることもできよう。ただし、崇高なも のを単にあがめるだけではすまず、それを守るために 他者を攻撃しょうとするところを除けばの話だが。

活動家たちのこうした見方が科学的方法と衝突すること は、しごく容易に想像できる。科学的方法とは、感情を排 して客観的計測と合理性を優先するものであり、また、自 らも批判的審問を受けることで前進するものだからである。 
しかし、この内在していた衝突が、多くの過激な環境 活動家がイメージする科学者像によってさらに大きく燃 え上がり、膨れ上がっている。彼らは科学者を、事実を 装った見解を表明する抑圧的なエリート階級だとみてい るのだ。こうした科学者の見解は、金持ちゃ権力者の利 益にかなうように簡単にねじ曲がるものだと、活動家の 多くが感じている。また、社会問題を科学的に解決する ともてはやされたもの（例えばDDT、サリドマイド、原 子力）が、うたい文句通りの成果を上げなかったと考元 る活動家もいる。そのため、この新世代の環境活動家の 多くは、科学技術に対して深い不信感を抱いている。 研究所やその他の標的への襲撃を引き起こす少数派 の新世代活動家たちには、若さ、情熱、そして抑えきれ ない自信がある。彼らは憤りを感じており、理想主義的 で、自分のなすべきことを感じ取り、切迫した気持ちに なっている。そして、自分が正義のために戦っていると 考えており、そのためにはもはや科学を必要としていな い。この点は創世記を信ずる人々と似ているが、これ以 外の点で両者の間に共通性はほとんどない。こうした環 境活動家の場合、真実とは自らの心の中から聞こえるも のだ。そして彼らは、個人主義的で相対主義的な文化に おいて、自分たちの意見も他人の意見も等しく正当だと 考えている。彼らは一部の研究を認めず、特に遺伝子操 作や動物実験が関係するものはいっさい容認しない。そ こで、「ドッカーン」とやるわけである。

こうした過激な活動を支援する数名の話によれ ば、長期にわたって辛抱強く行われた野外研究やコン ピューターモデル、入念なデー夕探索などは軽䔣の対 象でしかないのだという。環境は危機的状態にあり、 今こそ行動の時だと彼らは話す。彼らの中には、科学 それ自体に、維持するだけの価值がないと考えている 者もいる。科学とは、芯まで腐った文明の一側面だ、 と彼らは考えているのだ。

\section{主張の応酬}

科学的方法と真っ向から対立する規範があり、それが長 年の熱狂的な主張の応酬を通じて強化されてきたコミュ ニティーの人々に対して、なぜ科学者のほうからわざわ ざ対話をもちかけるべきなのだろうか。それは、この集 団がもっと大規模な環境保護運動の内部に影響力をもっ て抢り、したがって今日の政治状況に打いて強力で建設 的な要素となる可能性を秘めているからである。

科学界がこのようなむずかしい領域に対して影響力 を保持するための最も有力な手段は、自らのありのま まの姿を学校や大学、テレビ、そしてインターネット 上で熱心にたゆまずみせていくことである。その姿と は、エリートが上意下達で決めた一連の規範なででは なく、人類が直面する困難、もしくは解決困難に近い 山ほどの問題を調べる一連の方法である。

科学界とその支援者は、例えば自然の生息環境がぞ う機能しているかを知るうえで、科学がいかに役立つ かを強く主張すべきである。そうすることで、科学の 本質的要素がじっくりと育まれることになる。冷静さと 補足説明を十分に伴えば、ときには科学も政策立案者 の心を動かすことができる。また、技術の中にも貴重 な資源を浪費しないですむものがある。こうした技術 の多くは、むしろ貴重な資源を節約してくれるだろう。 過激派の中でも過激な ELF と「動物解放戦線」(ALF) の信奉者は、決して納得することはないだろう。しかし、 それほど過激ではないが環境について積極的に考元て いる支持者たちは、もっと大きなグループを形成して おり、各地でデモ行進に参加し、科学に対する見方も 共通している。もし研究者が感情的な主張を鼻であし らうことをやめ、科学の空を通してみれば、この世界 がより明確にみえることを実証していけば、このグルー プにいる大勢の人々が科学に抱く考元方を変える可能 性は高まるだろう。 